\title{
STRATEGI PENYULUHAN KELAUTAN DAN PERIKANAN DALAM MASA PANDEMI COVID-19 DI KECAMATAN PURWOREJO
}

\author{
Strategy for Countrying Marine and Fisheries in the Covid-19 Pandemic \\ Period in Purworejo District
}

\author{
Anggih Isti Choeronawati ${ }^{*}$, Nur Rochman \\ Dinas Pertanian Pangan Kelautan dan Perikanan Kabupaten Purworejo, Jawa Tengah \\ Jl. Mayjen Sutoyo No.29-31, Ngupasan, Kabupaten Purworejo, Jawa Tengah 54114 \\ *Alamat korespondensi: anggih.iksan2@gmail.com
}

(Tanggal Submission: 4 November 2020, Tanggal Accepted: 28 Desember 2020)

\begin{abstract}
ABSTRAK
Penyuluhan adalah proses pembelajaran bagi pelaku. Tidak hanya sekedar mendampingi atau memberikan informasi tetapi bisa berdampak bagi pelaku. Penyuluhan sangat diperlukan dalam pengembangan pelaku utama atau usaha agar mampu mandiri. Di Kecamatan Purworejo terdapat dua belas Pokdakan (Kelompok Pembudidaya Ikan) dan dua Poklahsar(Kelompok Pengolah dan Hasil Pemasaran). Namun di tengah kondisi pandemi Covid-19 yang melanda Indonesia dan berbagai negara dunia lainnya, penyuluh perikanan harus tetap melaksanakan tugas pendampingan dan pembinaan kepada masyarakat kelautan dan perikanan. Oleh karena itu perlu dilakukan strategi penyuluhan kelautan dan perikanan dalam masa pandemi covid-19 di Kecamatan Purworejo. Metode pelaksanaan sesuai dengan tugas dari kegiatan penguatan dan pendampingan kelompok pelaku utama perikanan yang dilakukan oleh Penyuluh Perikanan berdasarkan Keputusan Kepala Badan Riset Dan Sumber Daya Manusia Kelautan Dan Perikanan, Nomor : 1/KEP-BRSDM/2020 tentang Penyuluh Perikanan. Materi yang diberikan meliputi sosialisasi program-program KKP secara langsung kepada Pokdakan dan Poklahsar. Hasil yang didapatkan adalah tugas penyuluh perikanan tidak terbatas hanya sosialisasi persoalan kelautan dan perikanan saja. Di tengah musibah ini, penyuluh Kabupaten Purworejo ikut menyebarkan informasi kepada masyarakat bagaimana cara hidup yang sehat pada pandemi Covid19 serta menciptakan inovasi-inovasi, agar kegiatan penyuluhan tidak terhenti begitu saja.
\end{abstract}

Kata kunci : strategi, penyuluhan, perikanan, covid-19, Purworejo

\section{PENDAHULUAN}

Di Kecamatan Purworejo terdapat dua belas Pokdakan (Kelompok Pembudidaya Ikan) dan dua Poklahsar (Kelompok Pengolah dan Hasil Pemasaran). Jenis budidaya yang dilakukan oleh kelompok pembudidaya ikan meliputi budidaya lele, nila, gurame, dan ikan hias seperti koi. Sedangkan pengolahan yang dilakukan oleh kelompok pengolahan ikan meliputi pengolahan bakso ikan, nugget ikan, dimsum ikan, pempek ikan, abon ikan dsb.

Penyuluh perikanan merupakan bagian dalam peningkatan kualitas sumberdaya 
manusia kelautan dan perikanan, yaitu berperan dalam memberikan bimbingan dan pembinaan kepada pelaku utama, pelaku usaha dan masyarakat perikanan, sehingga meningkatkan wawasan, pengetahuan, keterampilan dan sikap dalam bidang kelautan dan perikanan, baik teknis maupun non teknis untuk pengembangan usaha di bidang kelautan dan perikanan. Fokus kegiatan penyuluh adalah pada pengembangan sumberdaya manusia sedangkan fokus sasaran adalah pada pemberdayaan pelaku utama dan pelaku usaha serta sumberdaya manusia lain yang mendukungnya (Fikri et al., 2017).

Namun di tengah kondisi pandemi Covid-19 yang melanda Indonesia dan berbagai negara dunia lainnya, penyuluh perikanan harus tetap melaksanakan tugas pendampingan dan pembinaan kepada masyarakat kelautan dan perikanan. Penyuluh perikanan harus tetap bekerja dalam menyosialisasikan programprogram KKP secara langsung kepada masyarakat. Sehingga diperlukan strategi penyuluhan kelautan dan perikanan dalam masa pandemi covid-19 di Kecamatan Purworejo kepada pelaku utama atau usaha Kelautan dan Perikanan agar kegiatan penyuluhan tidak terhenti begitu saja.

\section{METODE KEGIATAN}

Kegiatan dilaksanakan di Kecamatan Purworejo di dua belas Pokdakan (Kelompok Pembudidaya Ikan) dan dua Poklahsar (Kelompok Pengolah dan Hasil Pemasaran). Metode pelaksanaan sesuai dengan tugas dari kegiatan penguatan dan pendampingan kelompok pelaku utama perikanan yang dilakukan oleh Penyuluh Perikanan berdasarkan Keputusan Kepala Badan Riset Dan Sumber Daya Manusia Kelautan Dan Perikanan, Nomor : 1/KEP-BRSDM/2020 tentang Penyuluh Perikanan Bantu Tahun 2020 adalah

1. Menyusun Rencana Kerja Penyuluhan Perikanan.
2. Melakukan pembinaan/penyuluhan kepada pelaku utama dan / atau pelaku usaha KP.

3. Menumbuhkan Kelompok pelaku utama dan / atau pelaku usaha KP.

4. Melakukan penilaian kelas kemampuan kelompok pelaku utama perikanan.

5. Meningkatkan kelas kelompok pelaku utama dan / atau pelaku usaha KP.

6. Pembinaan kepada usaha mikro dan kecil sektor KP (UMK KP).

7. Pembinaan kepada Koperasi/ Koorperasi sektor KP.

8. Fasilitasi pelaku utama dan pelaku usaha kelautan dan perikanan dalam akses permodalan/pembiayaan usaha KP.

9. Fasilitasi pelaku utama dan pelaku usaha kelautan dan perikanan dalam akses pasar hasil perikanan.

10. Fasilitasi pelaku utama dan pelaku usaha kelautan dan perikanan dalam akses informasi dan Teknologi KP yang dibutuhkan.

11. Mensosialisasikan peraturan terkait kelautan dan perikanan kepada pelaku utama dan pelaku usaha kelautan dan perikanan.

12. Melakukan pendampingan kelompok dalam proses dan setelah mendapatkan Bantuan Pemerintah.

13. Melakukan pendataan dan / atau updating Kartu pelaku usaha kelautan dan perikanan.

\section{HASIL DAN PEMBAHASAN}

Kegiatan penyuluhan kelautan dan perikanan adalah suatu kegiatan yang memiliki tujuan yang jelas dan harus dapat dicapai. Oleh sebab itu, setiap pelaksanaan penyuluhan perikanan perlu dilandasi oleh strategi kerja tertentu demi keberhasilannya untuk mencapai tujuan yang diinginkan. Sebagai pertimbangan penentu strategi yang akan diterapkan, perlu diperhatikan beberapa hal yang menyangkut spesifikasi tujuan penyuluhan untuk mencapai sasaran pembangunan perikanan, identifikasi 
kategori pelaku utama, serta perumusan strategi penyuluhan untuk penerapan teknologi. Dengan demikian, setiap upaya penyuluhan perikanan kiranya perlu mengkaji kembali strategi penyuluhan yang menjamin semua kelompok pelaku utama dapat menikmati atau memperoleh informasi penyuluhan perikanan secara seimbang (Hanan A, 2010).

Safrida et al (2015) menyatakan bahwa penyuluh perikanan dalam pengembangan sektor perikanan memiliki peran. Peran yang dimiliki penyuluh sangatlah besar, mulai dari penyampaian informasi perikanan, penyaluran sarana produksi perikanan, serta peran penyuluh perikanan dalam proses pengolahan dan pemasaran hasil. Dalam strategi komunikasi, peranan komunikator sangatlah penting. Guna melancarkan komunikasi, komunikator sebaiknya mempergunakan pendekatan yang disebut AIDDA Procedure yang meliputi Attention, Interest, Desire, Decision, Action. Upaya tersebut dilakukan oleh para penyuluh perikanan dalam setiap melakukan kunjungan penyuluhan antara lain mereka berusaha membangkitkan perhatian dan minat dengan menanyakan perkembangan usaha mereka dan menggunakan cara-cara yang menumbuhkan rasa kedekatan dan kekeluargaan (Handrini, 2012).

Di tengah kondisi pandemi Covid-19 yang melanda Indonesia dan berbagai negara dunia lainnya, penyuluh perikanan tetap melaksanakan tugas pendampingan dan pembinaan kepada masyarakat kelautan dan perikanan sebagaimana mestinya. Pendampingan dan pembinaan tersebut antara lain menumbuhkan kelompok pelaku utama dan / atau pelaku usaha KP, melakukan penilaian kelas kemampuan kelompok pelaku utama perikanan, meningkatkan kelas kelompok pelaku utama dan / atau pelaku usaha KP, pembinaan kepada usaha mikro dan kecil sektor KP (UMK KP), pembinaan kepada
Koperasi/ Koorperasi sektor KP, fasilitasi pelaku utama dan pelaku usaha kelautan dan perikanan dalam akses permodalan/pembiayaan usaha KP, fasilitasi pelaku utama dan pelaku usaha kelautan dan perikanan dalam akses pasar hasil perikanan, fasilitasi pelaku utama dan pelaku usaha kelautan dan perikanan dalam akses informasi dan Teknologi KP yang dibutuhkan, mensosialisasikan peraturan terkait kelautan dan perikanan kepada pelaku utama dan pelaku usaha kelautan dan perikanan, melakukan pendampingan kelompok dalam proses dan setelah mendapatkan Bantuan Pemerintah serta melakukan pendataan dan / atau updating Kartu pelaku usaha kelautan dan perikanan. Sesuai dengan tugas Penyuluh Perikanan berdasarkan Keputusan Kepala Badan Riset Dan Sumber Daya Manusia Kelautan Dan Perikanan, Nomor : 1/KEPBRSDM/2020 tentang Penyuluh Perikanan Bantu Tahun 2020.

Penyuluh perikanan pada masa pandemi covid-19 melakukan pembinaan/penyuluhan kepada pelaku utama dan / atau pelaku usaha KP dengan menjaga kesehatan diri pribadi, keluarga, serta masyarakat binaan adalah menjadi sebuah keharusan. Menjaga pola hidup sehat dan mengikuti himbauan pemerintah menjadi penting. Oleh karena itu, tugas penyuluh perikanan tidak terbatas hanya sosialisasi persoalan kelautan dan perikanan saja. Di tengah musibah ini, penyuluh perlu ikut menyebarkan informasi kepada masyarakat bagaimana cara hidup yang sehat pada pandemi Covid-19. 


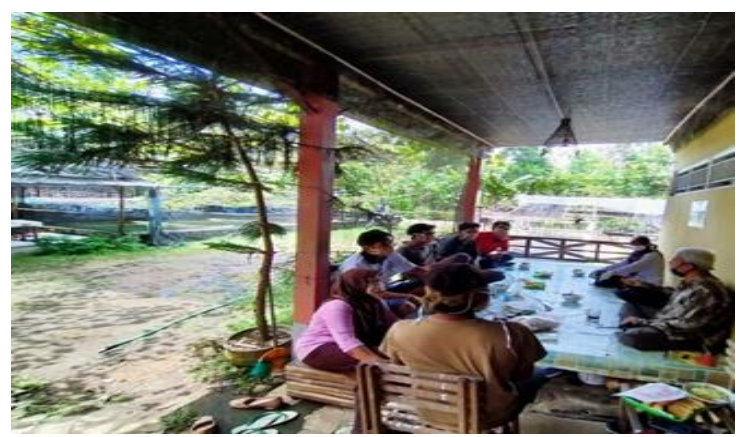

Gambar 1. Menyebarkan informasi kepada pelaku utama bagaimana cara hidup yang sehat dan protokol kesehatan yang dianjurkan

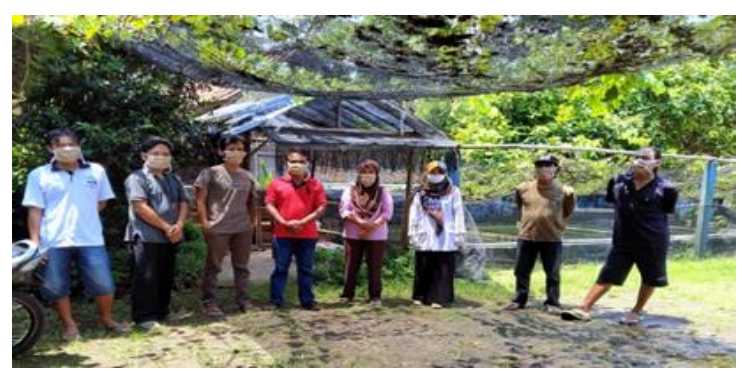

Gambar 2. Kegiatan penyuluhan dilakukan dengan memakai masker dan dengan melakukan social distancing atau jaga jarak

Penyuluh dalam melakukan pendampingan dan pelayanan kepada pelaku wajib melakukan terobosan-terobosan dan menciptakan inovasi-inovasi terutama pada masa pandemi covid-19, agar kegiatan penyuluhan tak terhenti begitu saja. Misalnya dengan memanfaatkan media digital yang ada. Contoh paling sederhana membangun WhatsApp Group sebagai media komunikasi penyuluh dengan masyarakat binaan, siaran radio maupun media lainnya untuk tetap menjaga produksi dan produktivitas usaha pelaku utama dan usaha Kelautan dan Perikanan.

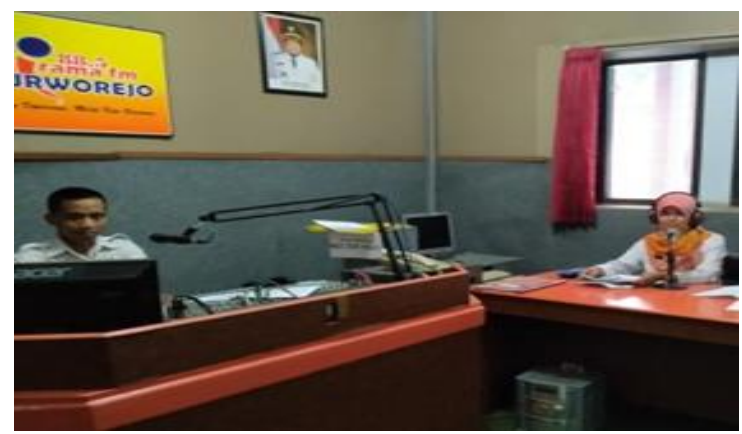

Gambar 3. Penyuluh memanfaatkan siaran radio untuk tetap melakukan pendampignan dan pelayanan serta menyebarkan informasi perikanan sebagai strategi penyuluhan

Pada saat bekerja dari rumah (Work Form Home), penyuluh perikanan tetap memberikan bantuan, membagikan informasi, ilmu pengetahuan teknologi melalui sarana digital. Meskipunw penyuluh bekerja dari rumah (Work From Home), namun penyuluh juga tetap ke lapangan. Saat ini pelaku utama dan usaha perikanan tidak hanya tengah berjuang menghadapi Covid-19, melainkan juga persoalan ekonomi sebagai dampaknya. Pelaku utama dan usaha terhambat untuk bergerak bebas seperti biasanya, sementara, mereka tetap harus bekerja dan menghasilkan pendapatan untuk memenuhi kebutuhan pangan dan kebutuhan lainnya.

Tugas penyuluh adalah sebagai pencerahan, memperkaya, bisa memberdayakan dalam pendampingan. Bagaimana penyuluh berkomunikasi juga penting (Sumardi,S dan Taryoto.A, 2013). Dalam pelaksanaan kegiatan penyuluhan perikanan, bukanlah suatu hal yang bisa ditangani secara mandiri oleh satu pihak namun memerlukan keterkaitan dan kerjasama antar lembaga yang terkait dengan pembangunan perikanan (Rina, 2013). Penyuluh merupakan mitra utama pelaku utama atau pelaku usaha sehingga dalam kegiatan penyuluhannya berkolaborasi dengan pemerintah daerah atau dinas setempat (Pusluh, 2013). 


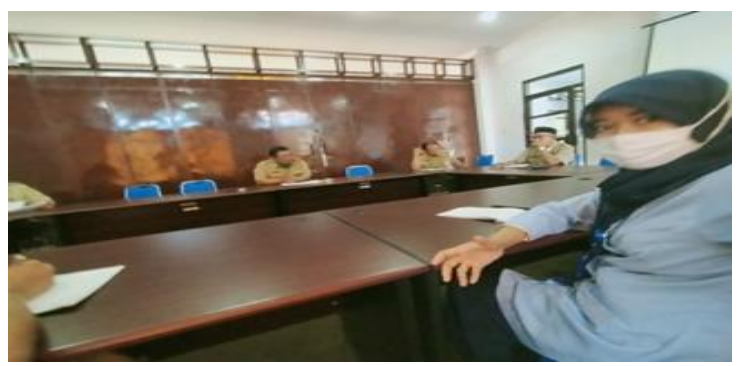

Gambar 4. Penyuluh melakukan koordinasi dengan dinas setempat terkait kegiatan penyuluhannya agar terjadi sinkronisasi kegiatan perikanan

Koordinasi tersebut digunakan untuk merumuskan program dan kegiatan kerja sama penyelenggaran penyuluhan perikanan, seperti kegiatan budidaya perikanan, pengolahan perikanan, penangkapan ikan yang meliputi pula pengawasan aktivitas penangkapan ikan diperairran umum (Permen KP Nomor 30, 2014). Adanya regulasi yang telah dibuat oleh Pemerintah tentunya harus diimbangi dengan pengawasan yang efektif. Disinilah peran penyuluh perikanan sangat penting dalam melakukan koordinasi dengan pemerintah daerah baik Kecamatan maupun Desa untuk melaksanakan pengawasan ini. Pemerintah juga harus menggandeng masyarakat dan pelaku usaha perikanan untuk bersama-sama mengawasi aktivitas perikanan yang berjalan dan kondisi lingkungan guna mewujudkan aktivitas perikanan yang berkelanjutan (KKP, 2014)

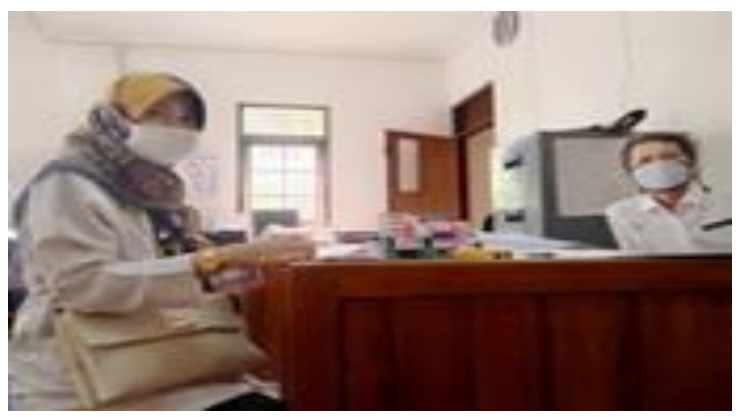

Gambar 5. Koordinasi dengan salah satu lurah di Kabupaten Purworejo terkait pengawasan aktivitas penangkapan ikan pada perairan umum (mensosialisasikan peraturan terkait KP)

Kecamatan Purworejo termasuk dalam zona merah persebaran covid-19. Penyuluh melaksanakan tugas penyuluhan kombinasi di lapangan dan dari rumah. Kegiatan penyuluhan dilapangan menjadi terbatas, namun tetap berjalan. Ketika ada kondisi urgent, penyuluh tetap terjun langsung kelapangan, meskipun harus ijin ke RT atau RW dan pos covid-19.

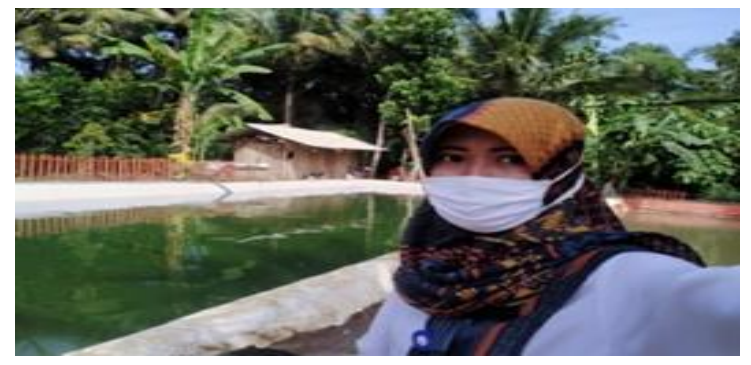

Gambar 6. Kondisi urgent ketika adanya laporan kematian ikan

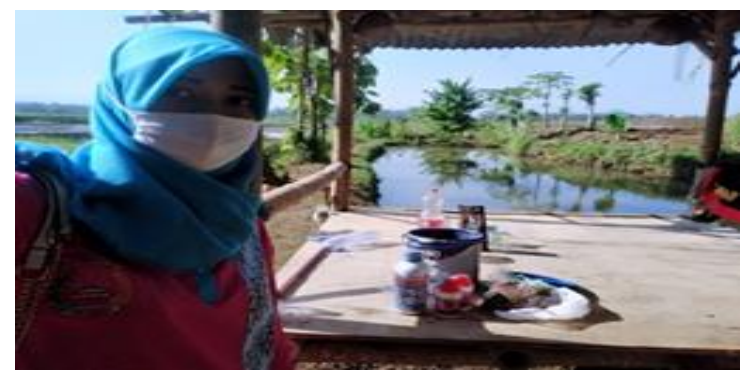

Gambar 7. Penyuluh menyalurkan obat untuk pelaku utama sekaligus memberikan penyuluhan bagaimana cara mengobati ikan sakit tersebut

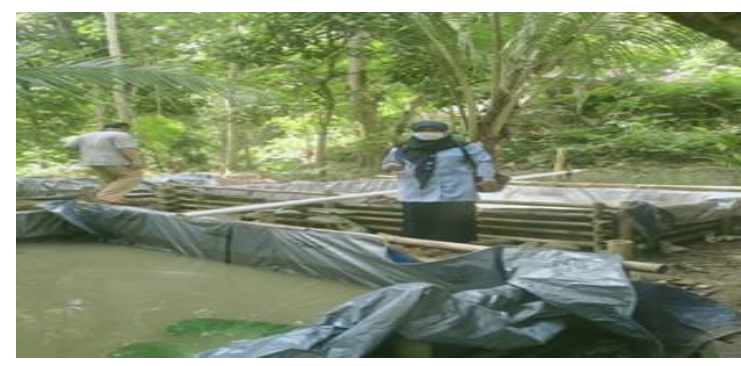


Gambar 8. Ketika pembudidaya membutuhkan penyuluh, penyuluh siap mendampingi kegiatan budidayanya

Pada masa pandemi covid-19, pendekatan penyuluhan yang lebih dominan digunakan adalah media online. Sehingga, kegiatan penyuluhan dalam pemilihan strategi penyuluhan harus memperhatikan tipe-tipe teknologi perikanan yang ingin disuluh untuk diterapkan para pelaku utama sasarannya. Baik yang berkaitan dengan kesesuaian teknologi dengan kondisi wilayah karakteristik teknologi itu sendiri, maupun karakteristik Pelaku Utama yang dijadikan sasaran penyuluhannya (Hanan A, 2010).

Dampak adanya covid-19 dirasakan hampir semua pelaku utama atau usaha Kelautan perikanan. Adanya over produksi atau hasil panen yang tidak terserap secara optimal oleh pasar menjadi permasalahan utama. Dalam kondisi seperti ini menjual secara eceran adalah pilihan yang tepat karena tidak mungkin menunggu pasar yang tidak pasti. Tugas penyuluh disini membantu akses pasar/ fasilitasi akses pasar. Bisa membantu lewat WhatsApp grup atau forum komunitas penjualan didaerahnya.

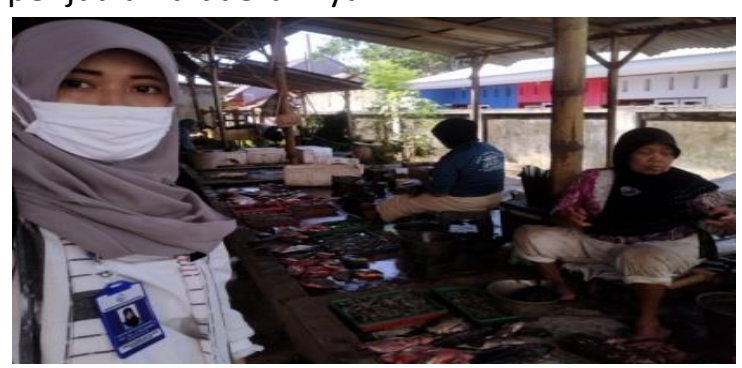

Gambar 9. Penyuluh membantu akses pasar

Dampak lain yang dirasakan oleh pelaku utama atau usaha budidaya antara lain siklus terhambat dan kehabisan modal usaha. Penyuluh memberikan pencerahan, memperkaya ilmu mengenai aspek informasi dan teknologi serta memberdayakan masyarakat Kelautan dan Perikanan bisa beradaptasi dengan cepat. Penyuluh menerapkan skala prioritas dan membuat rencana tindak lanjut dan aksi-aksi. Kendala lain pada usaha pengolahan adalah ketika pemasaran, tidak diperbolehkannya tempat jualan terdapat kerumunan warga sehingga peran penyuluh disini mengalihkannya ke frozen food, sehingga olahan bisa bertahan lama dan dapat dijual secara onlne maupun offline.

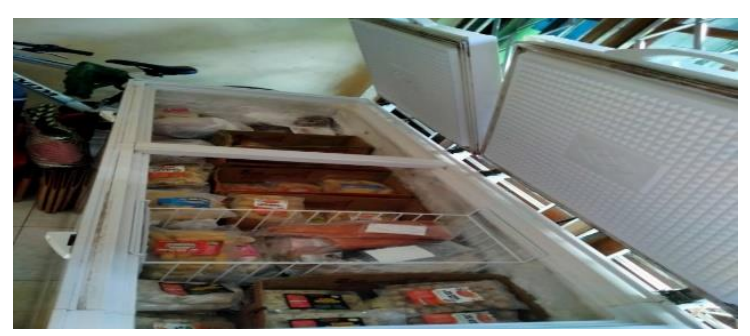

Gambar 10. Olahan Frozen food

Kerja penyuluh perikanan adanya covid-19 lebih ekstra, karena harus mendata ulang lagi pelaku yg terdampak covid-19 untuk diserahkan ke provinsi, ke dirjen tangkap, menampung aspirasi keluh kesah pelaku untuk disampaikan dinas. Kegiatan penyuluhan perikanan juga lebih banyak dialihkan ke pelatihan daring. Dimana para pelaku utama dan pelaku usaha perikanan bisa mengakses secara mandiri maupun kelompok dalam pelatihan online tersebut.

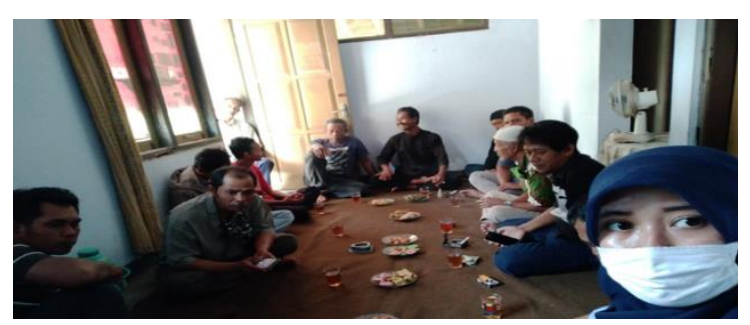

Gambar 11. Pendampingan pelatihan online kepada Kelompok Perikanan 


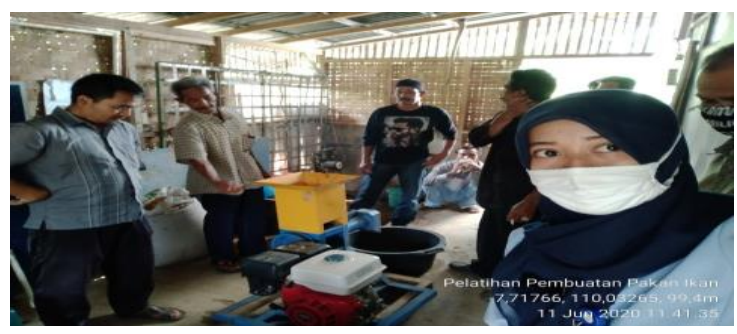

Gambar 12. Pendampingan pelatihan online pembuatan pakan ikan

Efektivitas komunikasi berdasarkan strategi komunikasi dalam kegiatan penyuluhan yang dilakukan, bahwa teknik kunjungan ke kelompok merupakan bentuk dan teknik penyajian pesan yang memiliki tingkat efektivitas tinggi guna menyampaikan pesanpesan penyuluhan kepada pelaku utama maupun pelaku usaha (Hikmayani et al, 2013). Hal ini yang banyak dilakukan penyuluh perikanan dalam strategi penyuluhannya, Meskipun kondisi saat pandemi ini juga dilakukan lewat media online, namun tidak sepenuhnya bisa dilakukan. Hal ini dikarenakan penyuluh harus turun langsung ke lapangan.

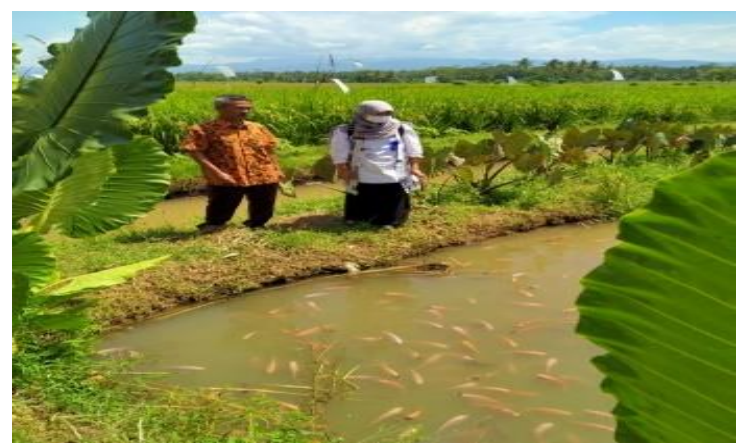

Gambar 13. Kegiatan pendampingan budidaya Mina Padi tetap dengan protokol kesehatan

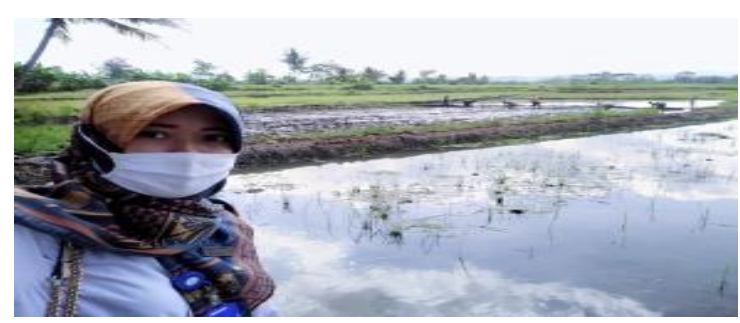

Gambar 14. Pemantauan pengolahan lahan untuk persiapan mina padi

Available online : http://abdiinsani.unram.ac.id Doi article : http://doi.org/10.29303/abdiinsani.v7i3.350

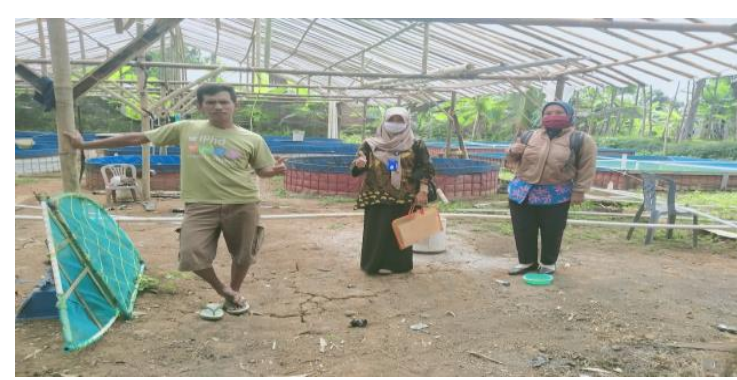

Gambar 15. Kunjungan ke kelompok pembudidaya dampak covid-19

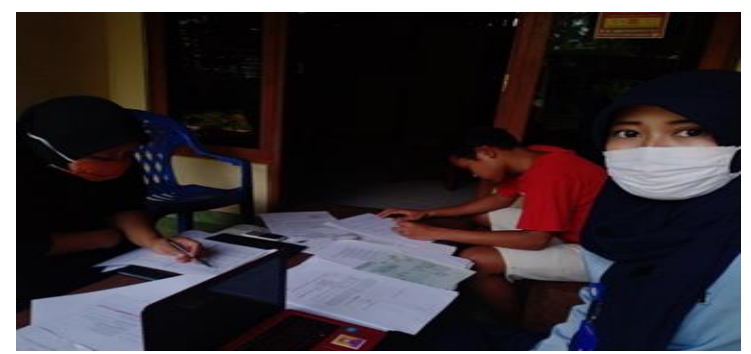

Gambar 16. Pendampingan pendataan kartu KUSUKA dan akses informasi dan teknologi KP

Penyuluh perikanan juga tetap bekerja dalam melakukan pendampingan kelompok dalam proses mendapatkan bantuan pemerintah, seperti sosialisasi dengan kelompok terkait bagaimana cara mengakses bantuan pemerintah serta pendampingan dalam pembuatan proposal bantuan pemerintah.

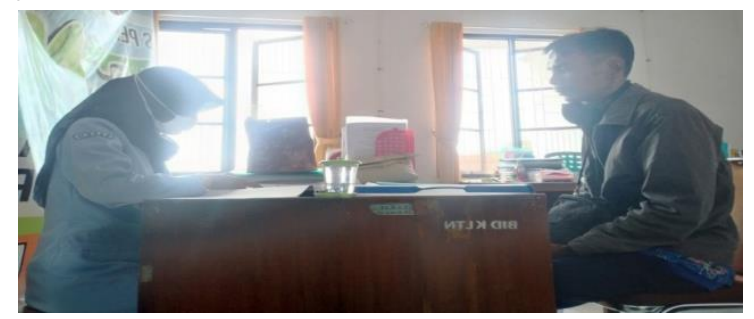

Gambar 17. Informasi terkait cara mengakses bantuan pemerintah 


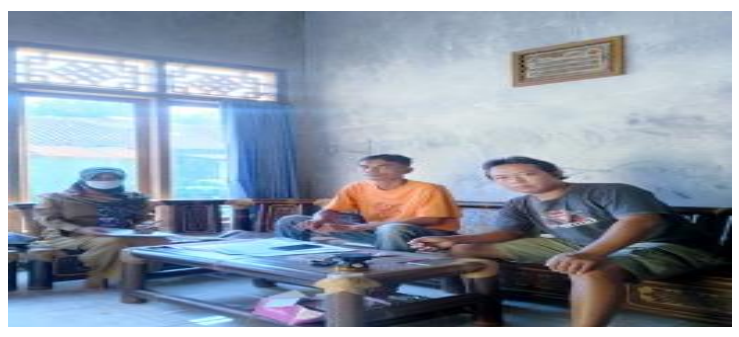

Gambar 18. Pendampingan dalam pembuatan proposal bantuan pemerintah

Pada masa pandemi covid-19, Penyuluh perikanan juga tetap melakukan pendampingan ke kelompok dalam kegiatan studi tiru dengan didampingi dinas perikanan setempat. Dengan kunjungan tersebut diharapkan pelaku utama dan usaha mampu menggali sebanyak mungkin informasi yang didapat secara teknis real, sehingga dapat mengembangkan usaha perikanannya.

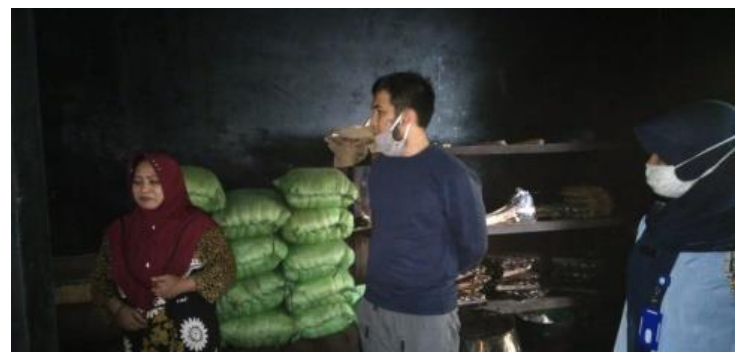

Gambar 19. Pendampingan Kegiatan Studi Tiru

Strategi penyuluhan perikanan tersebut diharapkan mampu memberikan bimbingan dan pembinaan kepada pelaku utama, pelaku usaha dan masyarakat perikanan, sehingga meningkatkan wawasan, pengetahuan, keterampilan dan sikap dalam bidang kelautan dan perikanan, baik teknis maupun non teknis untuk pengembangan usaha di bidang kelautan dan perikanan, serta mereka yang tengah berjuang menghadapi Covid-19 dapat menghasilkan pendapatan untuk memenuhi kebutuhan pangan dan kebutuhan lainnya.

\section{KESIMPULAN DAN SARAN}

Penyuluh masih bekerja dalam
menyosialisasikan program-program KKP

secara langsung kepada masyarakat, di tengah kondisi pandemi Covid-19 yang melanda Indonesia dan berbagai negara dunia lainnya, dengan berbagai strategi yang dilakukan. Dengan tetap menjaga kesehatan diri pribadi, keluarga, serta masyarakat binaan adalah menjadi sebuah keharusan. Menjaga pola hidup sehat dan mengikuti himbauan pemerintah menjadi penting. Oleh karena itu, tugas penyuluh perikanan tidak terbatas hanya sosialisasi persoalan kelautan dan perikanan saja. Di tengah musibah ini, penyuluh Kecamatan Purworejo ikut menyebarkan informasi kepada masyarakat bagaimana cara hidup yang sehat pada pandemi Covid-19. Saran agar penyuluh menciptakan inovasi-inovasi terutama pada masa pandemi covid-19, agar kegiatan penyuluhan tak terhenti begitu saja. Misalnya dengan memanfaatkan media digital yang ada. Contoh paling sederhana membangun WhatsApp Group sebagai media komunikasi penyuluh dengan masyarakat binaan, siaran radio maupun media lainnya untuk tetap menjaga produksi dan produktivitas usaha pelaku utama dan usaha Kelautan dan Perikanan.

\section{UCAPAN TERIMAKASIH}

Penulis mengucapkan terimakasih kepada Wasit Diono, S.Sos selaku Kepala Dinas Pertanian, Pangan, Kelautan dan Perikanan Kabupaten Purworejo, dan Eko Paskiyanto, A.Pi, MM selaku Kepala Bidang Kelautan dan Perikanan Kabupaten Purworejo, serta Joko Susanto, S.TP selaku koordinator penyuluh perikanan, pelaku utama dan usaha kelautan dan perikanan di Kecamatan Purworejo, serta rekan-rekan penyuluh perikanan di Kabupaten Purworejo dan semua pihak yang telah membantu. 


\section{DAFTAR PUSTAKA}

Handrini A. 2012. Sistem Penyuluhan Perikanan

Dalam Perspektif Komunikasi. Kajian, 17(1) : 53-75.

Fikri, H., Subekti dan Sofia., 2017. Peran Penyuluh Dalam Agribisnis Perikanan Air Payau Di Kabupaten Bangkalan Madura. JSEP, 10 (1) : 31-46.

Hanan A, 2010. Modul Dasar-dasar Penyuluhan Perikanan. Pusat Pelatihan Kelautan dan Perikanan, Jakarta.

Hikmayani, Y., Hayu D, R, dan Nasution, Z. 2013. Evaluasi dan Strategi Peningkatan Pelaksanaan Keberhasilan Pengembangan Usaha Mina Pedesaan Perikanan Budidaya (PUMP PB) : Pendekatan Analisis Prospektif. J. Kebijakan Sosek KP, 3(1) : 47-65.

Kementerian Kelautan dan Perikanan. 2014. Laporan Statistik Perikanan Tangkap Tahun 2012. Jakarta.

Keputusan Kepala Badan Riset Dan Sumber Daya Manusia Kelautan dan Perikanan Nomor 1/KEP-BRSDM/
2020 tentang Penyuluh Perikanan Bantu Tahun 2020.

Peraturan Menteri Kelautan dan Perikanan Republik Indonesia Nomor. 30/PERMEN-KP/2014 tentang Mekanisme Kerja Dan Metode Penyuluhan Perikanan.

Pusluh KKP, 2013. Pemantapan Sistem Penyuluhan Perikanan Menunjang Industrialisasi KP Sejumlah Masukan Pemikiran. Artikel penyuluhan, November 2013, (http://180.235.150.200/pusluh/ind ex.php/arsip/c/427/).

Rina. 2013. Mewujudkan Penyuluhan Perikanan yang Optimal. Majalah Infomina edisi Oktober/Th.IV/2013.

Safrida, T, Makmur dan Hafid. 2015. Peran Penyuluh Perikanan Dalam Pengembangan Sektor Perikanan Di Kabupaten Aceh Utara. Agrisep. 16(2).

Sumardi,S dan Taryoto.A.2013. Tinjauan Sistem Penyuluhan Perikanan (bagian kedua dari dua tulisan). Trobos.com tanggal 20 December 2013. Jakarta. 